\title{
Reconstrucción craneal con biomateriales. Revisión histórica y estado actual
}

\section{Cranial reconstruction with biomaterials. Historical revision and current state}

\author{
I. Zubillaga Rodríguez', G. Sánchez Aniceto', J.J. Montalvo Moreno²
}

Resumen: La reconstrucción de defectos craneofaciales es todavía hoy día un proceso desafiante. Se define craneoplastia como la reparación de un defecto o deformidad craneal.

La persistencia de traumatismos craneofaciales y procedimientos neuroquirúrgicos aporta un número importante de casos que permiten un fascinante progreso y desarrollo de nuevos materiales.

El objetivo de este artículo es la revisión histórica de los distintos métodos reconstructivos craneales empleados, comentando sus ventajas e inconvenientes según el tamaño y forma del defecto a reparar. Se presentan casos clínicos recientes reconstruidos con diversos biomateriales.

Palabras clave: Craneoplastia; Biomateriales.
Abstract: Craniofacial defect reconstruction is still a challenging procedure. A cranioplasty is the treatment of a cranial defect or a deformity.

Cranial injuries and neurosurgical procedures provide an important group of cases that allow the development of new materials and fascinating progress.

The aim of this article is a historic review of the different cranial reconstructive techniques used, describing advantages and drawbacks. The biomaterials applied in recent cases are presented.

Key words: Cranioplasty; Biomaterials.

Recibido: 19.01 .05

Aceptado: 06.10 .06

1 Médico Adjunto.

2 Jefe de Servicio.

Servicio de Cirugía Oral y Maxilofacial.

Hospital Universitario 12 de Octubre, Madrid, España

Correspondencia:

Ignacio Zubillaga Rodríguez

Servicio de Cirugía Oral y Maxilofacial.

Hospital Universitario 12 de Octubre

Avda. de Córdoba s/n.

28041 Madrid, España

E-mail: ignaciozubillaga@yahoo.es 


\section{Introducción}

La reconstrucción de defectos craneofaciales es todavía hoy día un proceso desafiante. Diferentes técnicas y materiales han sido empleados en la remodelación craneal. Especialmente la elección del material a implantar ha sido controvertida. Ésta depende del tamaño del defecto y de las condiciones del área receptora.

Se define craneoplastia como la reparación de un defecto o deformidad craneal. Las diversas técnicas de reconstrucción craneal o craneoplastias mezclan sin lugar a dudas los conceptos de arte y ciencia quirúrgica. Los distintos métodos propuestos para la reconstrucción craneal desde la prehistoria hasta la moderna medicina tratan de solucionar defectos craneales de múltiples etiologías. La persistencia de traumatismos craneofaciales y procedimientos neuroquirúrgicos aporta un número importante de casos que permiten un fascinante progreso y desarrollo de nuevos materiales.

\section{Revisión histórica}

Los trépanos craneales, procedimiento quirúrgico más antiguo conocido, fueron practicados por muchas civilizaciones en la antigüedad. En Perú existe una amplia evidencia que los "cirujanos" preincaicos realizaron dicho tratamiento 3000 años antes de Cristo (Fig. 1). Se han descubierto cráneos trepanados incaicos junto a conchas y placas de plata y oro. También existen evidencias de cráneos con estos materiales colocados in situ cubriendo el defecto craneal. El ejemplo más notable es un cráneo que data de 2000 antes de Cristo hallado en Cerro Colorado (región de Paracas, Perú). ${ }^{1}$ Presentaba un defecto frontal izquierdo cubierto con una placa de oro de $1 \mathrm{~mm}$ de espesor. Se comenta que en dichas civilizaciones la reconstrucción con metales preciosos quedaba reservada para las clases sociales altas mientras que el empleo de elementos más débiles y comunes se aplicaba a las clases sociales deprimidas.

En la cultura celta neolítica se han encontrado fragmentos de cráneo redondeados u ovalados presumiblemente procedentes de cráneos trepanados. En ocasiones presentaban un orificio central formando un "anillo", el cual poseía cierto carácter mágico. Un cráneo encontrado en Crichel Down (Reino Unido,1938) contenía un gran anillo que había sido recolocado en la cavidad trepanada original. Los márgenes craneales no demostraban evidencia de curación, de manera que la craneoplastia pudo ser realizada postmortem. Se demuestra, sin embargo, que el concepto de craneoplastia no era extraño a las antiguas culturas europeas.

Autores de la antigua Asia, Egipto, Grecia y Roma aportan pocas innovaciones respecto a las culturas previas. Es a partir del siglo XVI cuando se plantean nuevas "ideas" respecto a la reconstrucción craneal. Fallopius proponía que el hueso del trépano podía ser repues-

\section{Introduction}

The reconstruction of craniofacial defects is a challenging process even today. Different techniques and materials have been used for restructuring the skull. The choice of material to be implanted has always been particularly controversial. This depends on the size of the defect and the conditions of the receptor area.

Cranioplasty has been defined as the repair of a defect or cranial deformity. The different techniques for cranial reconstruction or cranioplasties undoubtedly mix the concepts of art and surgical science. The different methods proposed for cranial reconstruction, from prehistoric times until modern medicine, have tried to solve cranial defects of multiple etiologies. The persistence of craniofacial trauma and neurosurgical procedures provides a considerable number of cases that allows fascinating progress and the development of new materials.

\section{Historical revision}

Skull trephines, the oldest surgical procedure known, were practiced by many ancient civilizations. In Peru there is ample evidence that the pre-Inca "surgeons" carried out this treatment 3000 years before Christ (Fig. 1). Trephined Inca skulls have been found along side gold and silver shells and plates. There is also evidence of skulls with these materials placed in situ covering the cranial defect. The most notable example is a skull dated 2000 B.C. found in Cerro Colorado (Paracas region, Perú).' It had a left frontal defect that was covered with a $1 \mathrm{~mm}$ thick plate of gold. It has been mentioned that in these civilizations reconstruction with precious metals was reserved for the highest social class, while the use of weaker or more common elements was used for the lower social class.

In Celtic Neolithic culture, rounded or oval skull fragments have been found presumably from trephined skulls. On occasions they had a central orifice in the shape of a "ring", which had certain magical properties. A skull found in Crichel Down ( United Kingdom,1938) had a large ring that had been placed in the original trephined cavity. The skull margins showed no signs of healing, to the extent that the cranioplasty could have been carried out postmortem. It shows, nevertheless, that the cranioplasty concept was not unusual in ancient European cultures. 
to tras el procedimiento inicial si la duramadre no había sido violada. Si existían desgarros durales, el hueso era eliminado y se empleaba una plancha de oro. Ésta es quizá la primera descripción recogida de una verdadera craneoplastia. Algunos contemporáneos suyos como Paré no daban crédito a sus prácticas.

La primera craneoplastia exitosa con injerto óseo fue descrita por Job Janszoon van Meekeren, un cirujano holandés que trató a un noble ruso que había sufrido una pérdida de una porción craneal tras el impacto de una espada. Se procedió a la reconstrucción con un fragmento craneal de un perro muerto adaptándolo al defecto. El conocimiento del caso por parte de las autoridades competentes de la época significó la excomunión del paciente del país, sin tomar medida alguna contra el cirujano. ${ }^{1}$

A comienzos del siglo XIX, los nativos de los mares del Sur utilizaban la cáscara del coco como material para craneoplastia y en el reciente siglo $X X$ se empleó cuerno de búfalo como material reconstructivo.

Una gran variedad de materiales han sido empleados a lo largo de la Historia en la reconstrucción de defectos craneales. Ya desde el siglo pasado, se trata de encontrar el sustituto óseo ideal a emplear y se describen algunas de sus características como resistencia, maleabilidad, térmicamente no conductivo, esterilizable, inerte, radiolúcido, no magnético, disponible y barato.

Sin duda alguna, los sustitutos óseos metálicos han supuesto un gran avance en los biomateriales disponibles para la reparación craneal. El aluminio fue el primer metal en la historia reciente en emplearse. Inicialmente descrito por Booth y Curtis (1893), ${ }^{2}$ provocaba una importante reacción tisular, era epileptógeno y sufría una lenta desintegración, de manera que su uso no se generalizó.

Metales preciosos como el oro y la plata también fueron empleados a finales del siglo XIX. Gerster ${ }^{3}$ y Sebileau, ${ }^{4}$ respectivamente, describieron su aplicación como sustituto craneal. Entre sus desventajas destacaban el alto coste, la debilidad del metal en estado puro y, aplicado a la plata, la tinción del tejido adyacente.

El uso de plomo (Mauclaire, 1908), 5 provocó en algunos casos intoxicación sistémica por dicho metal implicando la retirada de las placas, decreciendo significativamente su popularidad.

Otros metales utilizados fueron el platino, vitalio, ticonio, cromo, molibdeno, caracterizados todos por su falta de maleabilidad.

El tantalio fue descubierto en 1802. Fue propuesto como agente para craneoplastias en 1942, tras experimentos en perros que no mostraban reacción tisular. Es radiopaco y las pruebas de imagen postoperatorias eran difícilmente valorables. Su empleo fue sustituido por compuestos acrílicos y por titanio.

Al finalizar la II Guerra Mundial, Boldrey, ${ }^{6}$ introdujo las mallas de acero, recomendadas inicialmente para defectos de pequeño tamaño dada su escasa resistencia a los traumatismos. Comparte muchas propiedades con el tantalio y su gran ventaja era su bajo coste.

\section{Estado actual}

El titanio es un elemento que fue descubierto en 1796 pero no llegó a estar disponible comercialmente hasta 1946, tras el proceso de reducción del tetraclorhidro de titanio. Simpson, ${ }^{7}$ en 1965 ,
Authors in ancient Asia, Egypt, Greece and Rome had very few innovations with regard to previous cultures. It was from the 16th century onwards that new "ideas" with regard to cranial reconstruction were raised. Fallopius proposed that trephined bone could be replaced after the initial procedure, if the duramater had not been broken. If there was a dural tear, the bone was eliminated and a gold plate was used. This is perhaps the first description made of a true cranioplasty. Some of his contemporaries such as Paré could not believe what had been carried out.

The first successful cranioplasty using a bone graft was recorded by Job Janszoon van Meekeren, a Dutch surgeon who treated a Russian noble who had lost part of his skull after being struck with a sword. The reconstruction was carried out with a fragment of bone from a dead dog that was adapted to the defect. When the competent authorities at the time heard of this, the patient was banished from the country but no measures were taken against the surgeon. ${ }^{1}$

At the start of the 19th century, the natives of the southern seas started to use coconut shell as cranioplasty material, and recently in the $20^{\text {th }}$ century buffalo horn was used as reconstruction material.

A great variety of materials have been used throughout history for the reconstruction of cranial defects. As from the last century attempts have been made to find the ideal bone substitute and some characteristics have been described such as resistance, malleability, heat non-conductive, sterilizable, inert, radiolucid, non-magnetic, disposable and cheap.

Without any doubt, metallic bone substitutes are a great advancement with regard to the biomaterials available for cranial repair. Aluminum was the first metal in recent history to be used. Initially described by Booth and Curtis (1893), ${ }^{2}$ considerable tissue reaction occurred. It was epileptogenic and slow disintegration took place, to the extent that its use did not become generalized.

Precious metals such as gold and silver were also used at the end of the $19^{\text {th }}$ century. Gerster ${ }^{3}$ and Sebileau, ${ }^{4}$ respectively described its use as a cranial substitute. Among the disadvantages were the high costs, weakness of the metal in its pure form and, with regard to silver, staining of adjacent tissue.

The use of lead (Mauclaire, 1908) 5 resulted in some cases in systemic intoxication by this metal, which required plate removal, and its popularity decreased significantly. Other metals that were used were platinum, vitallium, ticonium, chromium, molybdenum, all characterized by a lack of malleability.

Tantalum was first described in 1802. It was proposed as a cranioplasty agent in 1942, after experiments in dogs showed no tissular reaction. It is radiopaque and the postoperative imaging tests were difficult to evaluate. Its use was substituted by acrylic components and by titanium.

At the end of World War II, Boldrey ${ }^{6}$ introduced steel mesh, which was recommended initially for small defects 
fue el primero en emplearlo en reconstrucción craneal. Comparado con el tantalio, es mucho más radiolúcido y considerablemente menos caro. Otras ventajas son su biocompatibilidad y su alta resistencia mecánica. Es inerte, no carcinogénico ni alergénico.

La reconstrucción de defectos craneales con titanio se realiza con mallas. Fueron originalmente desarrolladas durante la Guerra de Vietnam. Con el paso del tiempo se han introducido refinamientos como la reducción del grosor, aumento de resistencia y maleabilidad. Previamente han sido empleadas en reconstrucción mandibular y en maxilares atróficos. Los buenos resultados obtenidos propiciaron un incremento en el número de aplicaciones.

Su uso está indicado en áreas que no soporten cargas y se emplea en las siguientes situaciones: ${ }^{8}$

1. reconstrucción inmediata en el tratamiento primario de fracturas conminutas craneales con pérdida de hueso en defectos de hasta $25 \mathrm{~cm}^{2}$. En estas situaciones las miniplacas no permiten habitualmente la fijación de todos los fragmentos óseos y por tanto la obtención de resultados estéticos óptimos.

2. tratamiento de irregularidades en el contorno craneal (Figs. 2 a 5).

Entre las ventajas de esta técnica reconstructiva destacan su alta biocompatibilidad y aplicabilidad (incluso en contacto directo con senos paranasales), fácil manejo, combinación posible con hueso u otros biomateriales, mínima alteración en las pruebas de imagen postoperatorias; presenta reconstrucciones tridimensionalmente estables en estructuras anatómicas complejas, sin morbilidad de la zona donante y con baja susceptibilidad de infección.

Janecka, ${ }^{9}$ presenta una amplia experiencia en empleo de mallas de titanio en cirugía de la base craneal. La tasa de complicaciones es del $5 \%$, si bien en gran parte aplicable a la calidad de los tejidos blandos.

Como ya hemos comentado, es posible la combinación de mallas de titanio con otros biomateriales como la

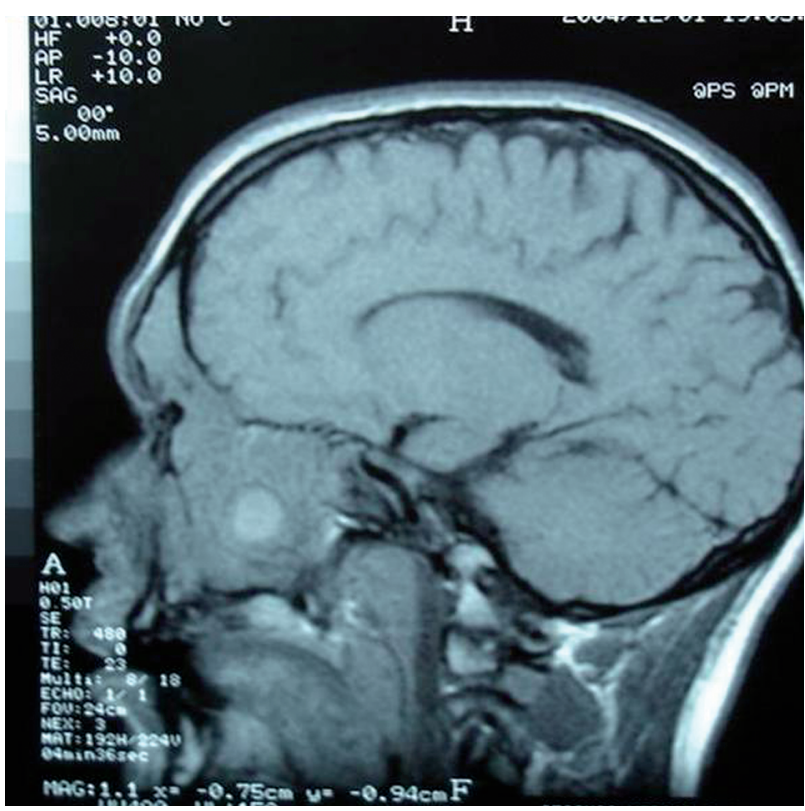

Figura 2. RM sagital. Pansinusitis. Mucoceles frontales.

Figure 2. Sagittal MRI. Pansinusitis. Frontal mucocele.

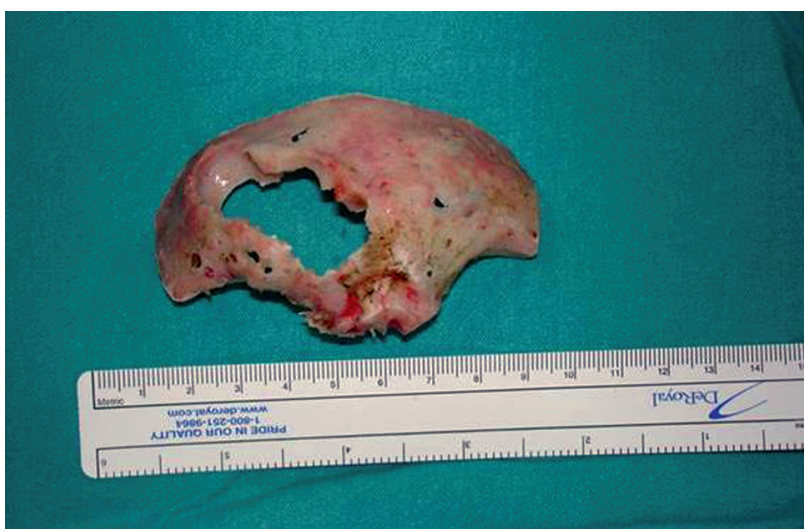

Figura 3. Abordaje subcraneal. Osteolisis pared anterior seno frontal.

Figure 3. Subcranial approach. Osteolysis of anterior wall of frontal sinus.

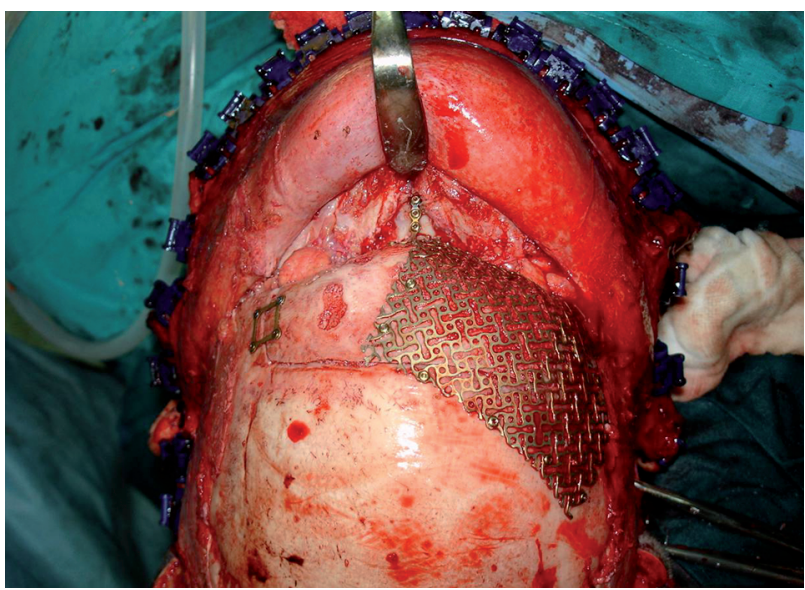

Figura 4. Reconstrucción craneal con malla de titanio. Figure 4. Cranial reconstruction with titanium mesh. given its limited resistance in trauma. It shared many of the properties of tantalum and its great advantage was its low cost.

\section{Current state}

Titanium is an element that was first discovered in 1796, but it was not commercially available until 1946, after the reduction process of titanium tetrachloride. In 1965 Simpson $^{7}$ was the first to use it in cranial reconstruction. Compared with tantalum, it is much more radiolucid and considerably less expensive. Other advantages are its biocompatibility and high mechanical resistance. It is inert, non-cancerous and non-allergic.

The reconstruction of cranial defects with titanium is carried out with mesh. It was originally developed during the Vietnam war. With the passage of time, refinements have been introduced such as a reduction in thickness, and increased resistance and malleability. It had previously been used for mandibular reconstruction and for atrophic maxillas. The good results obtained led to increased usage.

Its use is indicated in areas that cannot support loads and it is used in the following situations: 8

1. Immediate reconstruction during primary treatment of comminuted cranial fractures with bone loss defects of up to $25 \mathrm{~cm}^{2}$. In these situations the miniplates do not generally permit the fixation of all bone fragments and, therefore, the best aesthetic results are not obtained.

2. Treatment of irregularities around the skull (Figs. 2 to 5) 
hidroxiapatita (Figs. 6 a 9). La malla desempeña el papel de soporte estructural en la reconstrucción y el efecto osteoconductivo que aporta la hidroxiapatita permite un crecimiento óseo progresivo en el defecto craneal. ${ }^{10}$ Se crea así un ajuste tridimensional más preciso en el contorno craneal, aumentando la estabilidad y la resistencia a fuerzas de tensión. Permite la reconstrucción de defectos craneales moderados-extensos, mayores incluso de $25 \mathrm{~cm}^{2}$.

Algunos autores, ${ }^{11}$ defienden el empleo de una malla de titanio o reabsorbible interpuesta entre la duramadre y el cemento de hidroxiapatita para evitar que las pulsaciones cerebrales y de la dura puedan interferir en el fraguado del cemento. Sin la malla se provocarían pequeñas microfracturas en la hidroxiapatita que desencadenarían una inflamación local, infección y posterior extrusión y fracaso del implante. La combinación malla-hidroxiapatita no tiene un impacto negativo en la biocompatibilidad, osteoconductividad y capacidad de remodelado del cemento.

La incapacidad para obtener antiguamente radiografías fácilmente interpretables con el uso de metales para craneoplastia era un gran handicap y fue una de las primeras razones por la que muchos cirujanos trataron de descubrir y emplear nuevos sustitutos óseos no metálicos.

El desarrollo de nuestra especialidad $y$, en concreto, de la reconstrucción craneal se encuentra íntimamente relacionado con las grandes guerras a nivel mundial. Durante la II Guerra Mundial se produjeron una gran cantidad de defectos craneales. Aunque el tantalio era uno de los materiales de elección en dicha época, existía un creciente interés por las resinas de acrílico. Justo tras finalizar la II Guerra Mundial, dichas resinas eran empleadas como material para prótesis dentales con buenos resultados. A partir de ahí se propuso que podrían tener un papel importante en la reconstrucción craneal. Una de sus ventajas iniciales era su mayor radiolucidez.

Así, el metilmetacrilato fue descubierto en 1939. Entre sus cualidades incluía gran resistencia a la tensión y al

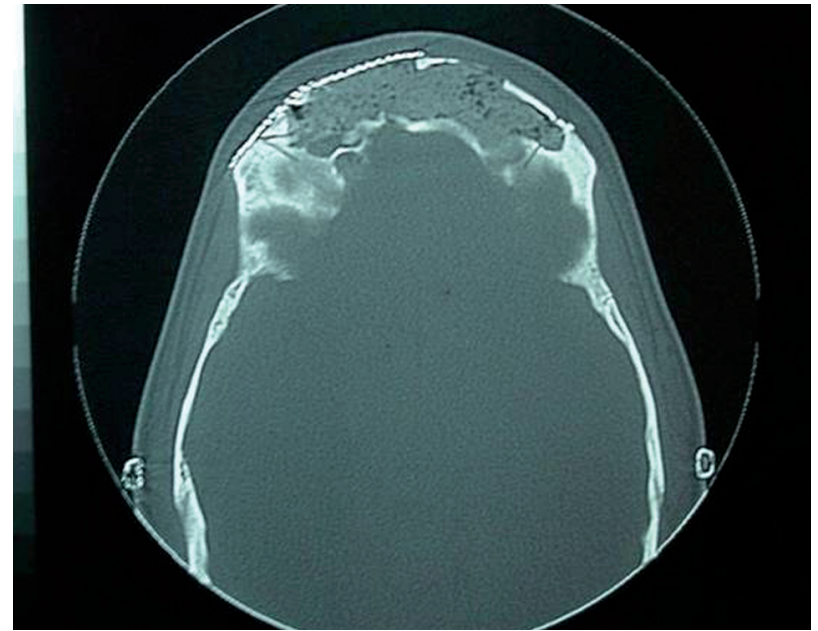

Figura 5. TC axial. Obliteración de senos frontales con viruta de calota y matriz ósea desmineralizada (DBX).

Figure 5. Axial CT scan. Obliteration of frontal sinuses with calvarial bone chip and demineralized bone matrix (DBX).

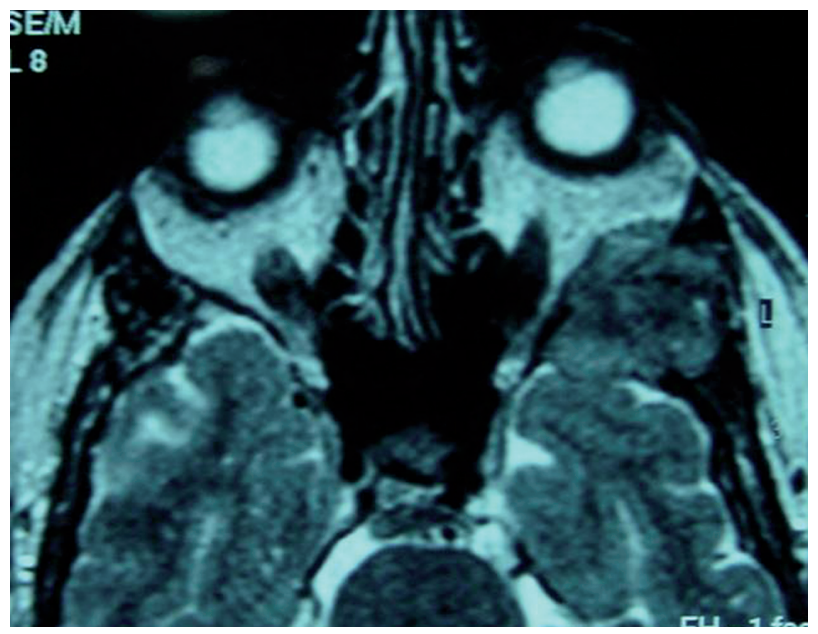

Figura 6. RM axial. Meningioma del ala mayor del esfenoides. Figure 6. Axial MRI. Meningioma of greater sphenoid wing.

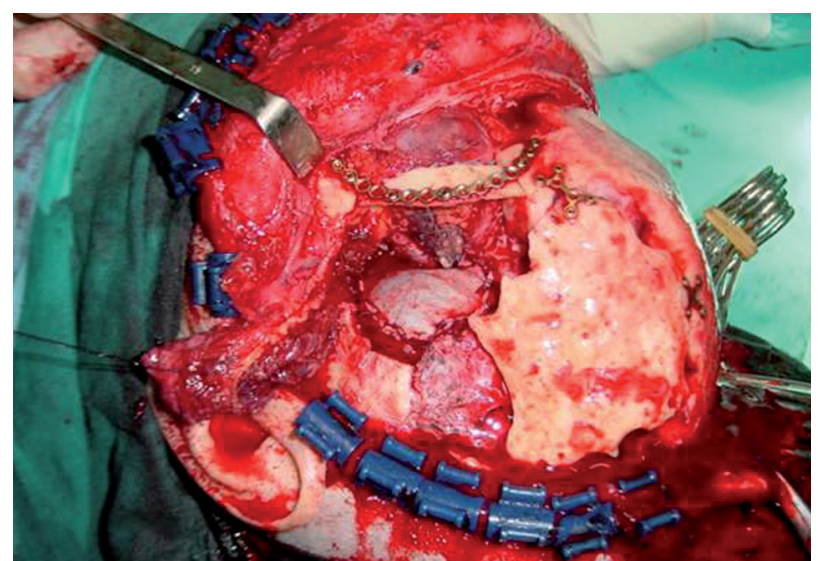

Figura 7. Lecho quirúrgico postresección. Plastia de duramadre. Colgajo de músculo temporal para sellado fosa craneal anterior. Figure 7. Surgical bed postresection. Duraplasty. Temporalis muscle flap for sealing anterior cranial fossa.
Among the advantages of these reconstructive techniques, the high biocompatibility and applicability stand out (even when in direct contact with the paranasal sinuses), together with easy handling, possibility of combining with bone or other biomaterials, and minimum disturbance in postoperative imaging tests. The tridimensional reconstructions in complex anatomic structures are stable, there is no morbidity in the donor area, and there is low susceptibility to infection.

Janeck $a^{9}$ presented a wide experience in the use of titanium mesh in skull base surgery. The rate of complications was 5\%, although this is partly due to the quality of the soft tissue.

As has been mentioned, a combination of titanium mesh with other biomaterials such as hydroxyapatite is possible (Fig. 6 to 9). The mesh provides structural support in the reconstruction, and the osteoconductive effect from the hydroxyapatite permits progressive bone growth in the cranial defect.10 A more precise tridimensional adjustment is in this way created, and stability and resistance to stress increases. And, the reconstruction of moderateextensive cranial defects that are even larger than $25 \mathrm{~cm}^{2}$ is possible.

Some authors ${ }^{11}$ defend the use of a titanium or resorbable mesh between the duramater and the hydroxyapatite cement in order to avoid any interference from the pulsations of the brain and the dura with 
calor. Es un material inerte. Fue empleado por primera vez de forma experimental como material para craneoplastia en un ratón en 1940. Zander, ${ }^{1}$ fue el primero en emplearlo en humanos en octubre del mismo año. En su evolución se han desarrollado placas preformadas y preesterilizadas que facilitan su empleo.

Actualmente es uno de los biomateriales más empleados en la reconstrucción craneal, quizá por su elevada resistencia a las fuerzas externas, su biodisponibilidad y bajo coste. Presenta una excelente biocompatibilidad con los tejidos adyacentes; sin embargo, se han descrito reacciones a cuerpo extraño tras su empleo con la consiguiente infección en el área quirúrgica de implantación..$^{12} \mathrm{~A}$ nivel intraoperatorio, la polimerización del polimetilmetacrilato da lugar a una reacción exotérmica significativa alcanzando temperaturas de hasta $80^{\circ}$. Se crea una reacción térmica que puede lesionar los tejidos adyacentes. Esto puede ser evitado empleando las previamente citadas placas moldeadas y preformadas (diseño tridimensional computerizado).

Es un material inerte (ausencia de sustitución ósea); no existe una integración efectiva con el hueso receptor. Persiste a largo plazo una interfase hueso-implante. Algunos estudios muestran una mejora en la osteointegración tras sumergir el implante en gel de ácido poliláctico-glicólico. ${ }^{13}$

La tasa de infección global se aproxima al 5\% según los distintos estudios. Sin embargo, Manson, ${ }^{14}$ muestra un éxito total sin infecciones en su serie de 42 craneoplastias con metilmetacrilato. Pacientes con reconstrucción simultánea craneal, orbitaria o nasal presentan una tasa de infección del $23 \%$. Los pacientes que desarrollan infección del implante han presentado previamente infección de la zona donde se coloca el metilmetacrilato. Para Manson dicho material es de elección en pacientes adultos con buena calidad de tejidos blandos sin historia previa de infección local.

HTR (Hard Tissue Replacement) es un polímero de polimetilmetacrilato- polihidroximetilmetacrilato. Presenta una alta resistencia a las fuerzas de compresión y biocompatibilidad. Contiene microporos en su estructura de 250-300 micrones, permitiendo teóricamente la invasión inicial de tejido fibrovascular y la posterior sustitución ósea. En su superficie existe una cubierta hidrófila con carga negativa que evita la adhesión bacteriana y disminuye por tanto el riesgo de infección.

Se realiza una TC tridimensional de alta resolución (cortes cada $\mathrm{mm}$ ) que determine el defecto de forma precisa y permita el dise-

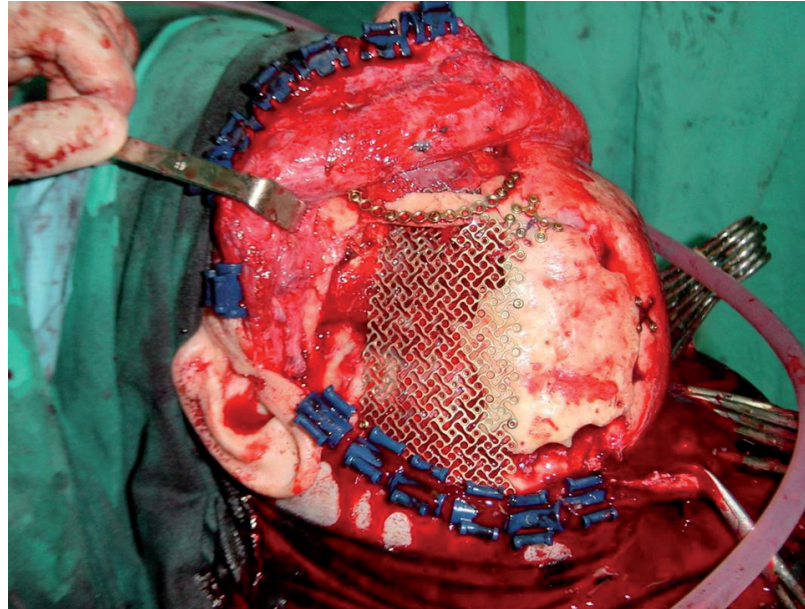

Figura 8. Malla de titanio para reconstrucción de defecto craneal. Figure 8. Titanium mesh for reconstruction of cranial fossa.

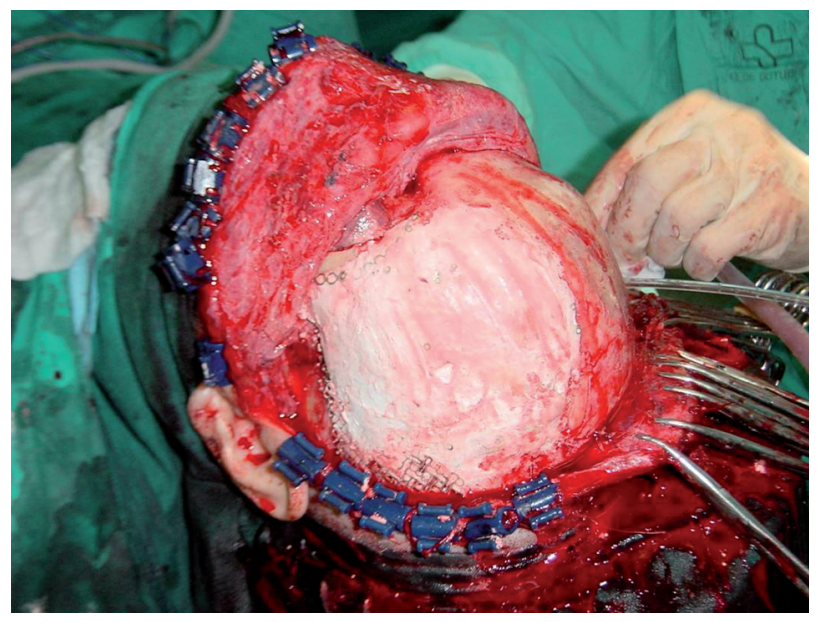

Figura 9. Malla de titanio con hidroxiapatita asociada, aumen-

Figure 9. Titanium mesh with hydroxyapatite for increasing tridimensional reconstructive stability. the setting of the cement. Without the mesh, there would be small microfractures in the hydroxyapatite that would start local inflammation and infection, together with the posterior extrusion and failure of the implant. The mesh-hydroxyapatite combination does not have a negative impact on the biocompatibility, osteoconductivity and restructuring capacity of the cement.

The use of metals for cranioplasties and the previous difficulties in obtaining radiographies that were easily interpreted, was a great handicap, and it was one of the main reasons behind the attempts by many surgeons to discover and use new bone substitutes that were not metallic.

The development of our specialty and of cranial reconstruction in particular, is closely related with wars on a worldwide scale. During World War II, a great number of cranial defects were produced. Although tantalum was one of the materials of choice in this era, there was growing interest in acrylic resins. Just after the end of World War II these resins were used as material for dental prostheses with good results. It was then suggested that they could play an important role in cranial reconstruction. One of the initial advantages was a greater radiolucency.

Methyl methacrylate was then discovered in 1939. Among its qualities was a great resistance to stress and heat. It is an inert metal and it was first used in an experimental way as cranioplasty material in a rat in 1940. Zander ${ }^{1}$ was the first to use it in humans in October of the same year. As it has evolved, preformed and sterilized plates have been developed which have facilitated its use.

It is currently one of the biomaterials most used in cranial reconstruction, perhaps because of its high resistance to external stress, its bioavailability and low cost. It has excellent biocompatibility with adjacent tissues. However, strange body reactions have been described after its use, with the 
ño del implante. Se precisa un software compatible con el de la empresa que manufactura el producto y 6-8 semanas de espera para la recepción del mismo. La fijación al cráneo se realiza con placas de titanio o reabsorbibles. ${ }^{15}$ Permite la reconstrucción de defectos craneales de más de $100 \mathrm{~cm}^{2}$ (Figs. 10 a 13).

Son muchos los biomateriales empleados a lo largo de la historia en la reconstrucción craneal. La búsqueda del biomaterial ideal es objeto de numerosos estudios clínicos. Parece lógico pensar que la sustitución ósea progresiva del implante es una condición indispensable para la obtención del biomaterial idóneo.

Ha sido introducida en las últimas décadas la hidroxiapatita como material útil en las distintas craneoplastias. Es el componente mineral primario del hueso, compuesto por moléculas de fosfato cálcico interconectadas formando una estructura hexagonal.

Inicialmente (mediados del siglo XX) estuvo disponible en formas cerámicas, creadas tras someter las preparaciones de fosfato cálcico a altas temperaturas. Poseen una porosidad limitada y su gran desventaja es que se trata de implantes preformados. ${ }^{16}$

En consecuencia, existió un gran ímpetu por desarrollar formas no cerámicas de hidroxiapatita (cementos) que pudieran ser moldeadas intraoperatoriamente hasta alcanzar el tamaño deseado. Fueron desarrollados en 1986 por la Asociación Dental Americana y aprobados por la FDA en 1996 para su aplicación en humanos. Estos implantes no son sometidos a altas temperaturas para su génesis (cristalización de la hidroxiapatita). Soporta inicialmente fuerzas de compresión menores que el PMMA. No es recomendado su uso en áreas que soporten cargas dado que su resistencia a las fuerzas de tensión es baja. Sus microporos favorecen la progresiva tendencia a la incorporación y posterior sustitución por el hueso nativo que lo rodea. Actúa como un material osteoconductor, debiendo estar en contacto con el hueso sano que lo rodea. Su composición implica ausencia de reacciones a cuerpo extraño, disminuyendo así el riesgo de infección y posterior extrusión. Puede ser empleada para la reparación de defectos craneales completos o en forma de injerto onlay sobre la cortical interna o

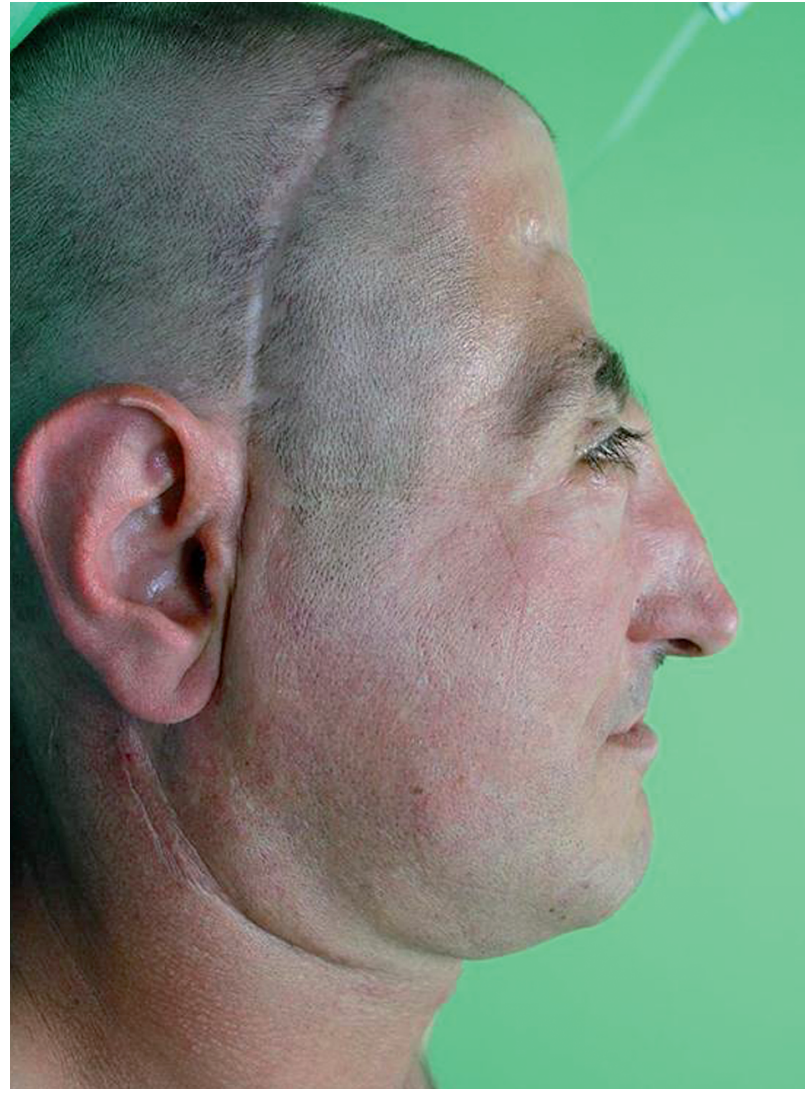

Figura 10. Defecto frontal postraumático. Osteomielitis crónica. Figure 10. Frontal region post-traumatic defect. Chronic osteomyelitis

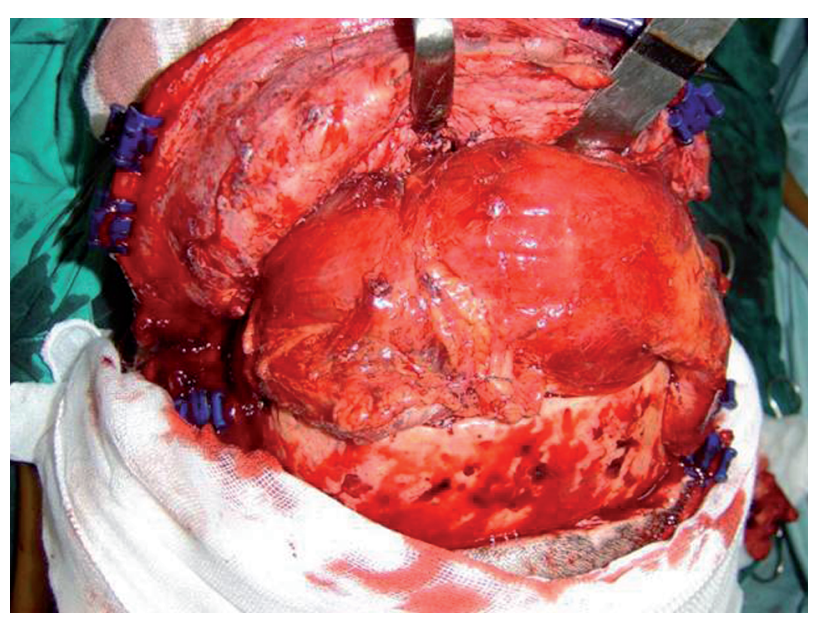

Figura 11. Colgajo de recto abdominal para el sellado de fosa craneal anterior y la eliminación del espacio muerto intracraneal.

Figure 11. Rectus abdominis flap for sealing anterior cranial fossa and for eliminating intracranial dead space. resulting infection in the surgical area of the implantation. ${ }^{12}$ At an intraoperative level, polymerization of polymethylmethcrylate gives rise to a significant exothermic reaction and temperatures of up to $80^{\circ}$ have been reached. There is thermal reaction that can damage adjacent tissues, but this can be avoided by using the previously mentioned preformed and molded plates (computerized tridimensional design). It is an inert material (absence of bone substitution) and there is no real integration with the receptor bone. There is a longterm bone-implant interphase. Some studies show an improvement in osseointegration after submerging the implant in polylactic-glycolic acid gel. ${ }^{13}$

The rate of global infection is around 5\% according to different studies. However Manson's ${ }^{14}$ series of 42 cranioplasties with methyl methacrylate was completely successful and there were no infections. Patients with simultaneous cranial, orbital or nasal reconstruction had an infection rate of $23 \%$. The patients that developed implant infection had experienced previous infection of the area where the methyl methacrylate had been placed. This is the material of choice, according to Manson, for those adult patients with good quality soft tissues and with no previous history of local infection.

HTR (Hard Tissue Replacement) is a polymer of polymethyl methacrylate-polyhydroxymethyl methacrylate. It is highly resistant to the forces of compression and it is biocompatible. It has micropores in its structure of 250-300 microns, which theoretically allow the initial invasion of fibrovascular tissue and posterior bone substitution. It has a layer of hydrophile on its surface with neg- 
díploe remanente (Fig.14). Si la reconstrucción craneal es de espesor total, es preciso asociar mallas que eviten la fragmentación de la hidroxiapatita en el proceso de fraguado por las pulsaciones durales. Además, facilitan el proceso de regeneración ósea guiada. Se han descrito tasas de infección de hasta un 5\%.

Es controvertido el efecto de este biomaterial en el crecimiento craneal. Aunque estudios en animales no han demostrado un efecto negativo en el crecimiento craneal, parece adecuado evitar su uso en los 4-5 primeros años de vida (el cerebro alcanza el $80 \%$ del tamaño adulto a los 2-3 años), periodo de crecimiento craneal más rápido. ${ }^{16}$

Aunque la hidroxiapatita tiene un papel importante en la reconstrucción craneal, el sustituto óseo ideal no ha sido hallado. Hasta la fecha no existe evidencia histológica de crecimiento óseo significativo en humanos tras un periodo de seguimiento de 3 años. Se están desarrollando estudios que aumenten el potencial osteogénico innato de la hidroxiapatita ( osteoinducción) combinándola con otros biomateriales tipo proteínas óseas morfogenéticas como la osteogenina o con el fosfato beta tricálcico. ${ }^{17}$

Sin duda, el futuro de la reconstrucción craneal está en las técnicas de biología molecular, tratando de desarrollar el proceso de osteoinducción mediado por las proteínas óseas morfogenéticas. En el futuro dichas proteínas impregnarán el implante, aportando así propiedades osteoconductivas-osteinductivas.

\section{Discusión}

Los defectos craneales pueden ser divididos en congénitos y adquiridos, siendo estos últimos los más frecuentes. En la mayoría de los casos se trata de defectos postraumáticos. Entre las patologías congénitas a reconstruir se encuentran los meningoceles, encefaloceles, forámenes parietales masivos, aplasia cutis con agenesia craneal, cráneos bífidos. Sin embargo, las técnicas quirúrgicas reconstructivas han de emplearse con más frecuencia en la corrección de los defectos craneales que surgen tras la corrección quirúrgica de las craneosinostosis. Dentro de la patología adquirida incluimos casos postraumáticos (craniectomías descompresivas), oncológicos (tras exéresis de hueso craneal o para relleno de fosa temporal tras empleo de músculo temporal) (Fig. 15), osteomielitis craneal... La región cra-

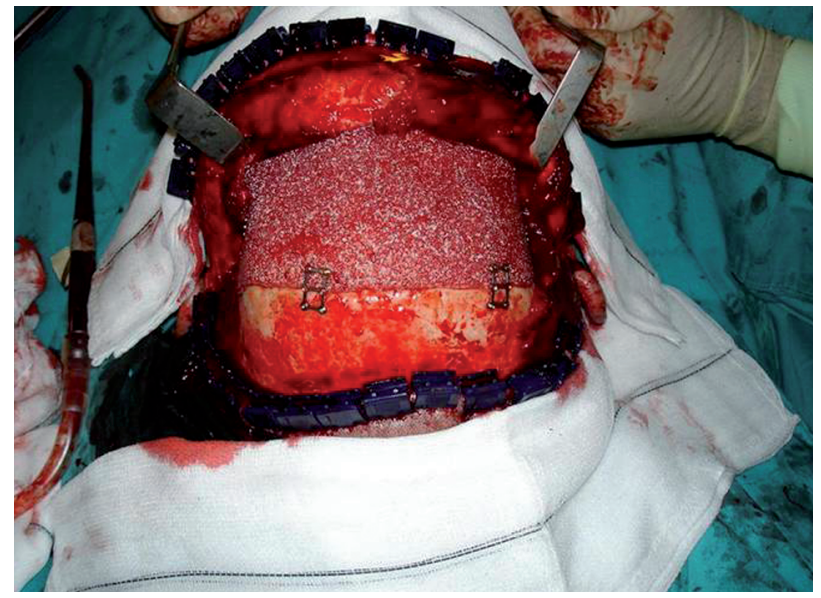

Figura 12. HTR frontal. Figure 12. Frontal HTR.

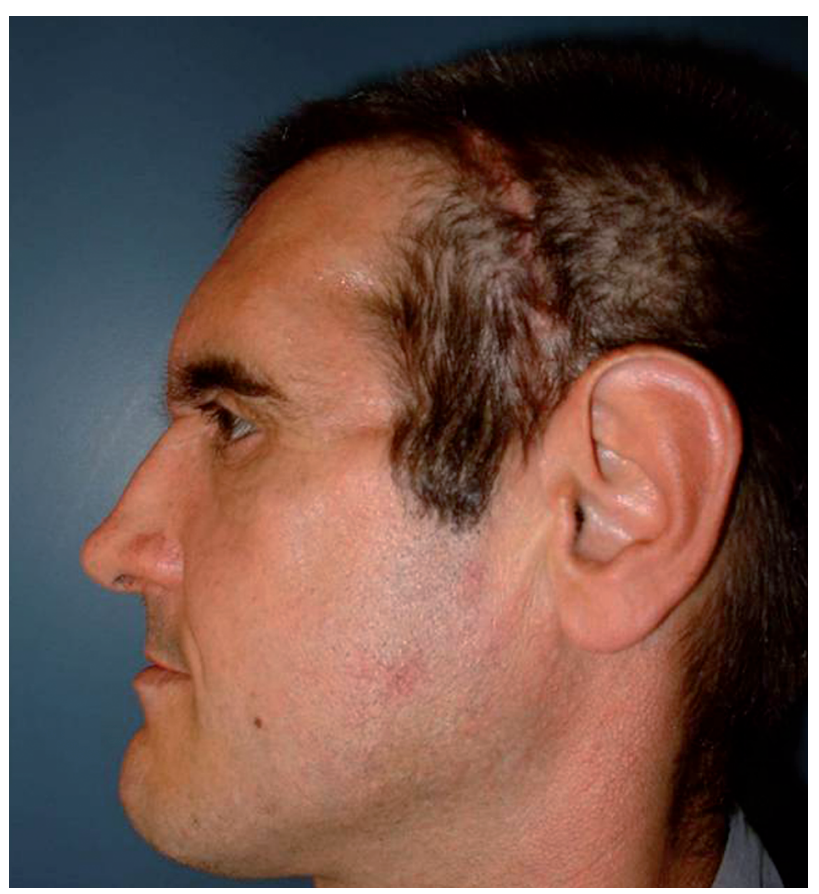

Figura 13. Imagen clínica postoperatoria.

Figure 13. Postoperative clinical view. ative charges that avoids bacterial adhesion and therefore reduces the risk of infection.

$A$ high resolution tridimensional CT scan (with slices every $\mathrm{mm}$ ) is carried out to define the defect in a precise fashion, in order to permit the design of the implant. Software that is compatible with that of the company manufacturing the product is required, and until the implant is received there will be a 6 8 week waiting period. It is fixed to the skull with titanium or resorbable plates. ${ }^{15}$ Cranial defects of more than $100 \mathrm{~cm}^{2}$ can be reconstructed (Figs. 10 to 13).

Many biomaterials have been used over time for reconstructing the skull. Looking for the ideal biomaterial has been the object of numerous clinical studies. It would appear logical that progressive bone substitution of the implant is an indispensable condition for procuring suitable biomaterial.

Over the last decades hydroxyapatite has been introduced as beneficial material in different cranioplasties. It is the primary mineral component of bone, and it is composed of interconnected calcium phosphate molecules that form a hexagonal structure.

It was initially available (in the middle of the 20th century) in a ceramic form that had been created after the calcium phosphate preparations had been subjected to high temperatures. They were of limited porosity and their great disadvantage was that they consisted of preformed implants. ${ }^{16}$

As a result there was a drive to develop non-ceramic forms of hydroxyapatite (cement) that could be molded intraoperatively until the right size was achieved. They were developed in 1986 by the American Dental Association and approved by the FDA in 1996 for human use. These implants were not subjected to high temperatures when created (hydroxyapatite crystallization). Initially they could with- 
neal más frecuentemente reconstruida es la región frontal.

En general, con la excepción de defectos craneales en niños menores de 3-4 años, no existe osteoneogénesis craneal propiamente dicha. Defectos pequeños, particularmente aquellos cubiertos por músculo (excepto en la región frontal) pueden no requerir craneoplastias. Tampoco está indicado en áreas que soporten cargas. En el resto de los casos son planteables técnicas reconstructivas craneales por dos motivos claros:

1. Consideraciones estéticas.

2. Protección frente a traumatismos.

Muchos factores pueden retrasar la corrección quirúrgica craneal. Sin embargo, se recomienda un mínimo de 3 meses de espera en casos postraumáticos y un mínimo de 6 meses en casos con infecciones locales, previa instauración de tratamiento antibiótico crónico.

Son muchas las características descritas que debe poseer un biomaterial, si bien no se ha encontrado el ideal. Entre ellas se encuentra la biocompatibilidad, fuerza, resistencia a la fractura y a la conducción térmica, inerte, esterilizable, bajo coste, radiolucidez, maleabilidad, osteoactividad. ${ }^{18}$

Asimismo, presentan ventajas frente a los injertos autógenos, como ausencia de morbilidad en la zona donante, disponibilidad, ausencia de reabsorción, fáciles de moldear, resultado cosmético superior. La mayor desventaja es que no dejan de ser cuerpos extraños, desencadenando ocasionalmente reacciones inflamatorias locales que pueden dar lugar a infecciones locales, provocando la extrusión y el fracaso del implante.

Es difícil atribuir muchas de las complicaciones exclusivamente al material que vamos a implantar, estando íntimamente asociadas a la técnica quirúrgica, respuesta del huésped y condiciones locales de la zona a recontruir. ${ }^{19}$ Quizá no sea tan importante el biomaterial a emplear y sí la calidad de las partes blandas de la región receptora del implante y el adecuado manejo de los senos paranasales que pudieran estar implicados.

La creación de un espacio muerto intracraneal puede surgir tras la realización de una craneoplastia, bien por retracción dural cicatricial bien por pérdida de masa encefálica. El manejo de dicha situación es controvertido, pudiendo optar por el aislamiento estricto de los senos paranasales con colgajos locales, ${ }^{20}$ frente a la obliteración completa del espacio muerto mediante colgajos libres microvascularizados (Fig. 16).21

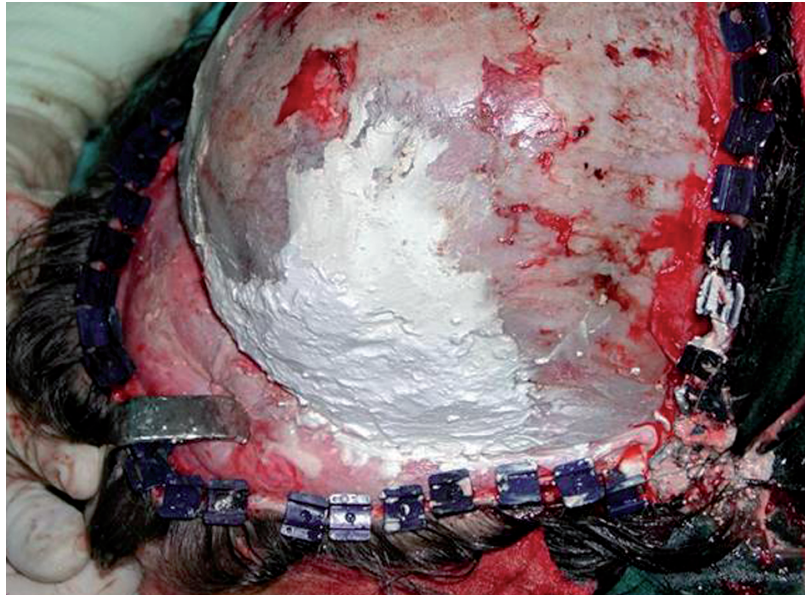

Figura 14. Corrección de irregularidades craneales con hidroxiapatita en paciente con craneosinostosis intervenida.

Figure 14. Correction of cranial irregularities with hydroxyapatite in patients operated for cranial synostosis.

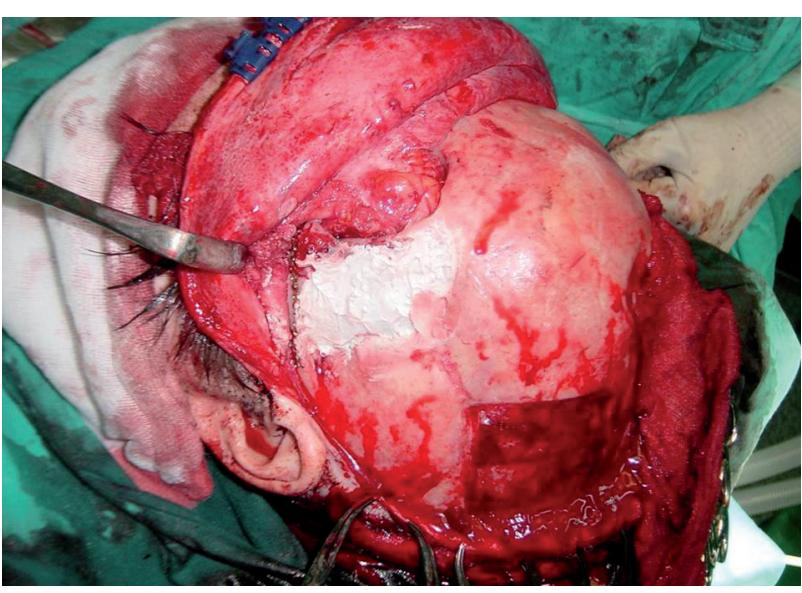

Figura 15. Camuflaje de fosa temporal con hidroxiapatita. Figure 15. Temporal fossa camouflaged with hydroxyapatite. stand lower forces of compression than PMMA. Their use in areas that cannot take loads is not recommended, as the resistance to stress is low. The micropores favor a progressive tendency to be incorporated and later substituted by the native bone surrounding it. It acts as osteoconductive material, and it should be in contact with the healthy bone surrounding it. Its composition implies the absence of strange body reactions, and the risk of infection and posterior extrusion is reduced. It can be used for repairing complete cranial defects or as an onlay graft on the internal cortical or remaining diploe. (Fig. 14). If the cranial reconstruction is of total thickness, using mesh to avoid the fragmentation of the hydroxyapatite is necessary in the setting process because of the pulsations of the dura. In addition, the process of guided bone regeneration is facilitated. Infection rates of up to $5 \%$ have been described.

The effect of this biomaterial is controversial in cranial growth. Although studies with animals have not demonstrated a negative effect in skull growth, avoiding its use during the first 4-5 years of life would seem appropriate (the brain reaches $80 \%$ of its adult size at the age of 2-3), the period with the fastest cranial growth. ${ }^{16}$

Although hydroxyapatite plays an important role in cranial reconstruction, the ideal bone substitute has not been found. There is to date no histological evidence of significant human growth after a follow-up period of 3 years. Studies are being developed that increase the osteogenic potential of hydroxyapatite (osteoinduction) by combining it with other biomaterials such as morphogenetic bone proteins or with tricalcium beta phosphate. ${ }^{17}$

The future of cranial reconstruction undoubtedly lies in molecular biology techniques, and in attempting to develop osteoinduction processes using morphogenetic bone proteins. In the future these proteins will impregnate the implant, providing osteoconductive-osteoinductive properties. 


\section{Conclusiones}

La obtención de un resultado clínico satisfactorio en la reconstrucción craneal depende de:

1. Selección de un biomaterial que reproduzca la estructura rígida craneal según el tamaño y forma del defecto.

2. Lecho receptor óptimo que favorezca la estabilidad de la reconstrucción a largo plazo y la vascularización del implante, manteniendo el resultado estético perseguido.

3. Manejo adecuado de los senos paranasales (Fig. 17).

\section{Bibliografía}

1. Sanan A, Haines S. Repairing holes in the head: a history of craneoplasty. Neurosurgery 1997; 40: 588-603.

2. Booth JA, Curtis BF. Report of a case of tumor of the left frontal lobe of the cerebrum: Operation-Recovery. Ann Surg 1893;17:128-39.

3. Gerster AG. Heteroplasty for defect of skull. Trans Am Surg Assoc 1895;13:485-6.

4. Sebileau S. Réparations craniennes par plaques osseuses. Lyon Med 1903;126:140-1.

5. Mauclaire P. Prosthese d'ivore pour reparer les pertes de substance du crane. Soc Chir Bull Mem 1914;40:113-5.

6. Boldrey E. Stainless steel wire-mesh in the repair of small cranial defects. Ann Surg 1945;121: 821-825.

7. Simpson D. Titanium in cranioplasty. J Neurosurg 1965;22:292-3.

8. Kuttenberger J, Hardt N. Long-term results following reconstruction of craniofacial defects with titanium micro-mesh systems. / Craniomaxilofac Surg 2001;29:75-81.

9. Janecka I. New reconstructive technologies in skull base surgery. Arch Otolaryngol Head Neck Surg 2000;126:396-401.

10. Ducic Y. Titanium mesh and hydroxyapatite cement cranioplasty: a report of 20 cases. J Oral Maxillofac Surg 2002;60:272-6.

11. Losee J y cols. Reconstruction of the inmature craniofacial skeleton with a carbonated calcium phosphate bone cement: interaction with bioresorbable mesh. J Craniofac Surg 2003;14:117-24.

12. Feith R. Side -effects of acrilic cements implanted into bone: a histological, angiografic, fluorescence-microscopic and autoradiografic study in the rabbit femur. Acta Orthop Scand 1975;161:3.

13. Dean D y cols. Osseointegration of preformed polymethylmethacrylate craniofacial prostheses coated with bone marrow impregnated poly foam. Plast Reconstr Surg 1999;104:705-12.

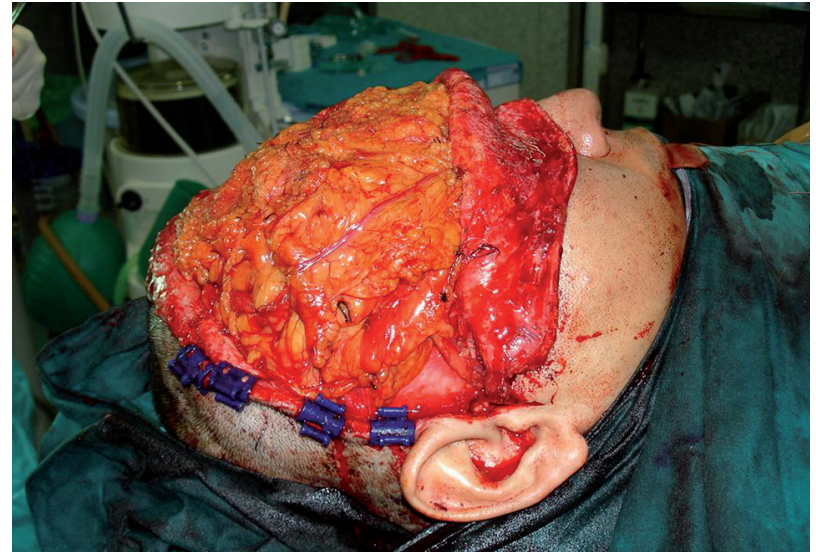

Figura 16. Colgajo libre de epiplon para el sellado de la fosa craneal anterior.

Figure 16. Omental free flap for sealing anterior cranial fossa.

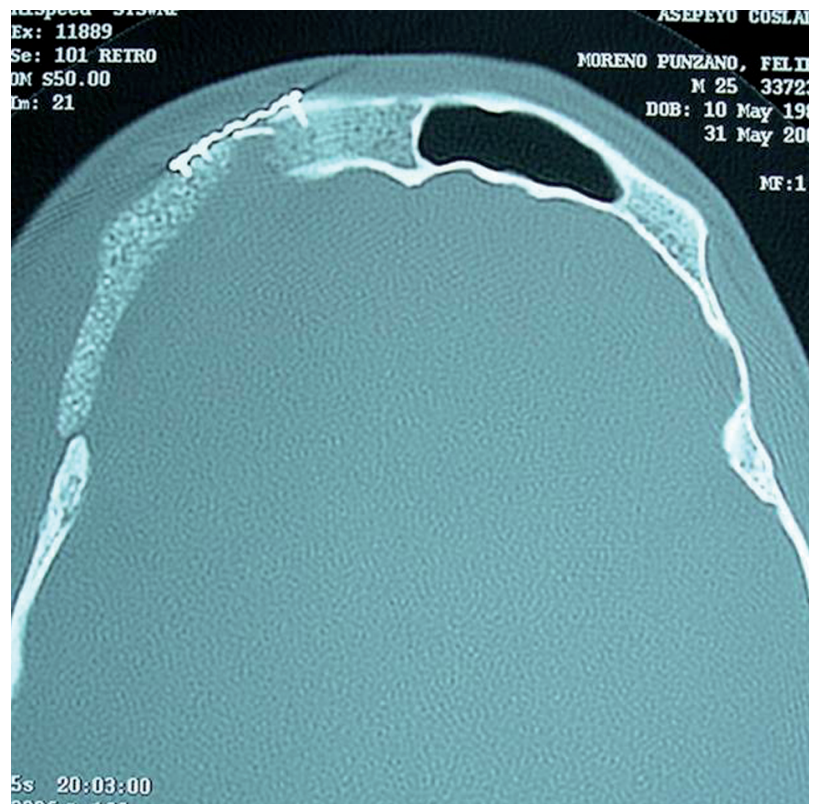

Figura 17. Craneoplastia frontotemporal postraumática. Manejo del seno frontal implicado.

Figure 17. Frontotemporal cranioplasty following trauma. Management of affected frontal sinus.
Discussion

Cranial defects can be divided into congenital or acquired defects, with the latter being the most common. In most cases these are post-traumatic defects. Among the congenital pathologies to be reconstructed are meningoceles, encephaloceles, massive parietal foramen, aplasia cutis with skull agenesis, and cranium bifida. However, reconstructive surgical techniques are used more frequently for correcting the cranial defects that may appear after surgical correction of craniosynostosis. Post-traumatic cases should be included within acquired pathologies (decompressive craniotomies), together with oncological cases (after exeresis of cranial bone or for filling the temporal fossa after using the temporalis muscle) (Fig.15), cranial osteomyelitis... The cranial region most commonly reconstructed is the frontal region.

In general, with the exception of cranial defects in children under the age of 3-4, there is no cranial osteoneogenesis so to speak. Small defects, particularly those covered by muscle (except in the frontal region) may not require cranioplasties. Neither is it indicated for areas supporting loads. In the remaining cases, skull reconstruction techniques are proposed for two clear motives:

1. Aesthetic considerations

2. Protection against trauma

Many factors can delay surgical correction of the skull. Nevertheless, a minimum delay of 3 months is recommended in post-traumatic cases, and a minimum of 6 months for cases with local infection in order to establish chronic antibiotic treatment.

Many desirable properties have been described with regard to biomaterials, although the ideal characteristic has 
14. Manson P,Crawley W, Hoopes J. Frontal craneoplasty: risk factor and choice of cranial vault reconstructive material. Plast Reconstr Surg 1986;77:888.

15. Eppley B. Craniofacial reconstruction with computer-generated HTR patient matched implants: use in primary bony tumor excision. / Craniofac Surg 2002;13:650-7.

16. Hollier $\mathrm{L}$, Stal $\mathrm{S}$. The use of hydroxyapatite cements in craniofacial surgery. Clin Plastic Surg $2004 ; 31: 423-8$.

17. Gosain A y cols. A 1 year study of osteoinduction in hydroxyapatite derived biomaterials in an adult sheep model: part II. Plast Reconstr Surg 2004;114:115563.

18. Gosain A. Biomaterials for reconstruction of the cranial vault. Plast Reconstr Surg 2005;116:663-6.

19. Younghoon R. Biomaterials in craniofacial reconstruction. Clin Plastic Surg 2004;31:377-85.

20. Lee Ch, Antonyshyn O, Forrest C. Cranioplasty: indications, technique and early resuls of autogenous split skull cranial vault reconstruction. J Craniomaxillofac Surg 1995;23:133-42.

21. Netscher d. Management of residual cranial vault deformities. Clin Plast Surg 1992;19:301-3. not been found. Among these there is biocompatibility, strength, resistance to fractures and to thermal conduction. It should also be inert, sterilizable, low cost, radiolucent, malleable and it should have osteoactivity. ${ }^{18}$

There are also advantages over autogenous grafts, such as the absence of morbidity in the donor site, availability, absence of resorption, easy contouring, superior cosmetic result. The greatest disadvantage is that it is still a strange body, and on occasions local inflammatory reactions will start, that may result in local infection, which will then lead to extrusion and implant failure.

Attributing many of the complications just to the material to be implanted is difficult, as there is a close connection with surgical technique, host response and local conditions in the area to be reconstructed. ${ }^{19}$ Perhaps the biomaterial used is not that important, and what is important, is the quality of the soft tissue in the receptor area of the implant and the adequate management of the paranasal sinuses that may be involved.

An intracranial dead space may be created after carrying out a cranioplasty, either because of dural retraction because of healing, or because of a loss of brain tissue. How this situation should be handled is controversial. The strict isolation of the paranasal sinuses with local flaps can be chosen20 as opposed to the complete obliteration of the dead space with microvascularized free flaps ${ }^{21}$ (Fig. 16).

\section{Conclusions}

Obtaining a satisfactory clinical result in cranial reconstruction depends on:

1. The selection of a biomaterial that reproduces the rigid cranial structure according to the size and shape of the defect.

2. Having an optimum receptor bed that favors the longterm stability of the reconstruction, and the vascularization of the implant, while in keeping with the desired aesthetic result.

3. Adequate management of the paranasal sinuses (Fig. 17). 